Article

\title{
Sustainability Education in the Spanish Higher Education System: Faculty Practice, Concerns and Needs
}

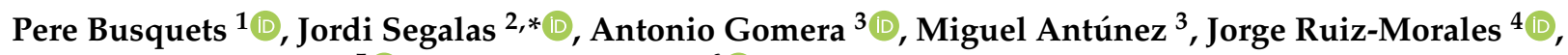 \\ Silvia Albareda-Tiana ${ }^{5}(\mathbb{B})$ and Rafael Miñano ${ }^{6}$ (b) \\ 1 Department of Mining, Industrial and ICT Engineering, Universitat Politècnica de Catalunya-Barcelona Tech, \\ 08034 Barcelona, Spain; pere.busquets@upc.edu \\ 2 Research Institute for Sustainability Science and Technology, Universitat Politècnica de Catalunya-Barcelona \\ Tech, 08034 Barcelona, Spain \\ 3 Environmental Protection Service (SEPA), University of Córdoba, 14071 Cordoba, Spain; \\ a62gomaa@uco.es (A.G.); a12anlom@uco.es (M.A.) \\ 4 Faculty of Educational Sciences, University of Sevilla, 41004 Sevilla, Spain; jruiz2@us.es \\ 5 Faculty of Educational Sciences, Universitat Internacional de Catalunya, 08195 Sant Cugat del Vallès, Spain; \\ salbareda@uic.es \\ 6 Innovation and Technology for Development Center, Universidad Politécnica de Madrid-UPM Madrid, \\ 28040 Madrid, Spain; rafael.minano@upm.es \\ * Correspondence: jordi.segalas@upc.edu
}

\section{check for}

updates

Citation: Busquets, P.; Segalas, J.; Gomera, A.; Antúnez, M.;

Ruiz-Morales, J.; Albareda-Tiana, S.; Miñano, R. Sustainability Education in the Spanish Higher Education System: Faculty Practice, Concerns and Needs. Sustainability 2021, 13, 8389. https://doi.org/10.3390/ su13158389

Academic Editors: Marc A. Rosen and Jin Su Jeong

Received: 31 May 2021

Accepted: 22 July 2021

Published: 27 July 2021

Publisher's Note: MDPI stays neutral with regard to jurisdictional claims in published maps and institutional affiliations.

Copyright: (c) 2021 by the authors. Licensee MDPI, Basel, Switzerland. This article is an open access article distributed under the terms and conditions of the Creative Commons Attribution (CC BY) license (https:// creativecommons.org/licenses/by/ $4.0 /)$.
Abstract: This article presents the results of the EDINSOST project in relation to the university faculty's practice concerns and the need to embed sustainability education in the Spanish Higher Education system. Four questions were devised to determine (1) which conceptions the university faculty has about sustainability in the context of the Spanish higher education (2) what sustainability competencies the university faculty holds (3) the ways in which sustainability teaching strategies are implemented and (4) the ways in which practical coursework related to sustainability is undertaken in a Spanish university context. The methodology that was applied was comprised of a discourse analysis of faculty focus groups. To that end, a category system and a focus group implementation protocol were designed and validated, as well as processes of construct elaboration based on the analysis of the focus groups' discourses. Among the most relevant contributions stemming from the research questions regarding the faculty's assumptions was the evidence that the holistic conception of sustainability is not addressed in all its dimensions and the environmental dimension is overemphasised. The need for training to teach sustainability competencies and the faculty's lack of awareness were also identified. As far as sustainability teaching strategies are concerned, project-based learning prevails, with service-learning emerging as the most effective strategy, even though its application is hindered by faculty training gaps. Finally, the absence of sustainability in teaching guides and study plans and the scarce institutional support for establishing sustainability as a strategic subject in the university were significant findings.

Keywords: sustainability; sustainable development; education for sustainable development; higher education; university faculty' perception; focus groups

\section{Introduction}

The 2030 Agenda for Sustainable Development provides a blueprint of 17 Sustainable Development Goals (SDG) with 169 integrated and undivided objectives involving the economic, social and environmental spheres. In addition to eradicating world poverty, the SDOs aim to eradicate hunger and achieve food safety; to ensure healthy lives, quality education, gender equality, and water and energy availability; to promote sustainable economic growth; to adopt urgent measures against climate change; and to promote peace and provide access to justice [1]. 
Both the 2030 Agenda and the United Nations Sustainable Development Solutions Network regard higher education as fundamental in securing the sustainable development of our planet and achieving their objectives [2].

Target 4.7 of the SDG 4 regarding education specifically addresses education for sustainable development (ESD) and identifies it as key to reach sustainability [3]. The 2030 Agenda shares the view that the solutions to the sustainability problems humanity faces do not depend as much on technology and its advancement, but on achieving change in behaviour. According to the Climate Change Synthesis Reports, the causes of the global atmosphere warming are of anthropogenic origin and the negative effects cannot be mitigated unless there is a change in human behaviour $[4,5]$. Therefore, the future of humanity depends on ethical responsibility. The majority of the dilemmas that need to be solved are above all ethical, political and also educational [6].

The university, as an open space for thought, reflection and action, is called to be at the forefront in developing strategies and methods that will enable solutions to the multiple global and local level challenges [7] such as the SDGs, and in this regard UNESCO (2017) [8] considers education in sustainability as a key element. In order to be capable of contributing towards transforming society, universities need to transform themselves first [9]. In this regard, in recent decades, universities have passed from trying to make the campuses greener $[10,11]$ to trying to make education and research more sustainable [12-22]. When making universities more sustainable, teaching is revealed as a challenging process to address $[11,19,23-26]$, even though there is evidence suggesting that the true nature of the necessary changes are not being understood [27].

Higher education must contribute to the training of active graduates who are committed to sustainable development $[28,29]$, who can act as catalysts in society and/or accelerators towards sustainability $[8,30]$. This catalyst role relies mainly on faculty and their training [31].

The higher education model based on teaching-learning by competencies has proposed interesting changes, including focusing the process on the students, pushing the professor's role change towards that of a tutor/dynamism enabler/facilitator and promoting strengths and methods consistent with sustainability [22,32-36]. The key process to make the curricula sustainable involves introducing sustainability content and criteria in study plans, so that the students are provided with the knowledge, abilities, attitude and values that allow their professional development within the sustainable development framework [37].

Previous research publications have revealed that this integration has been carried out in a very uneven way depending on the analysed university. Instabilities have been observed in teaching on the different dimensions of sustainability. Universities develop their economic and environmental aspects more than their social and ethical ones, and in general, a holistic view of sustainability is not presented [38].

This research is realised in the framework of the EDINSOST Project: "Education and social innovation for sustainability. The training of professionals as agents of change to face society challenges" [39,40] financed by "I + D + i State Program aimed at Society Challenges", and the "Guidelines for the Introduction of Sustainability in the Curriculum", of the Executive Committee of the CRUE'S Environmental Quality and Sustainable Development Working Group [41]. The project analyses 15 university degrees in the areas of engineering, the economy and education, by 60 researchers of 10 Spanish universities: Universidad Autónoma de Madrid (UAM), University of Cádiz (UCA), University Camilo José Cela (UCJC), University of Córdoba (UCO), University of Girona (UdG), Universitat Internacional de Catalunya (UIC), Universitat Politècnica de Catalunya (UPC), Universidad Politécnica de Madrid (UPM), University of Sevilla (US) and the University of Salamanca (USAL). 


\section{Materials and Methods}

\subsection{Objective}

The general objective of the EDINSOST Project is to forward education innovation in Sustainable Development Education (SDE) in Spanish universities, in order to provide future graduates with the necessary competencies to catalyse change towards a more sustainable society.

It is indisputable that university faculty have a fundamental role in this process. Knowing their perceptions, difficulties and motivations is imperative to be able to fulfil university faculty needs. This research is part of the EDINSOST Project's Objective 3: A diagnosis of the state of SDE with university faculty as a previous step to elaborate a training proposal to the faculty.

The following research questions were posed:

1. Which conceptions do the university faculty have about sustainability in the context of Spanish higher education?

2. What sustainability competencies do the university faculty hold?

3. In which ways are sustainability teaching strategies implemented?

4. In what ways is practical coursework related to sustainability undertaken in a Spanish university context?

\subsection{Methodology}

To answer these questions, the authors carried out qualitative research addressing them specifically and in an interrelated manner. The method applied (Figure 1) was comprised of a discourse and content analysis of university faculty focus groups, for which the authors designed a category system, a focus group implementation protocol and a process to elaborate constructs.

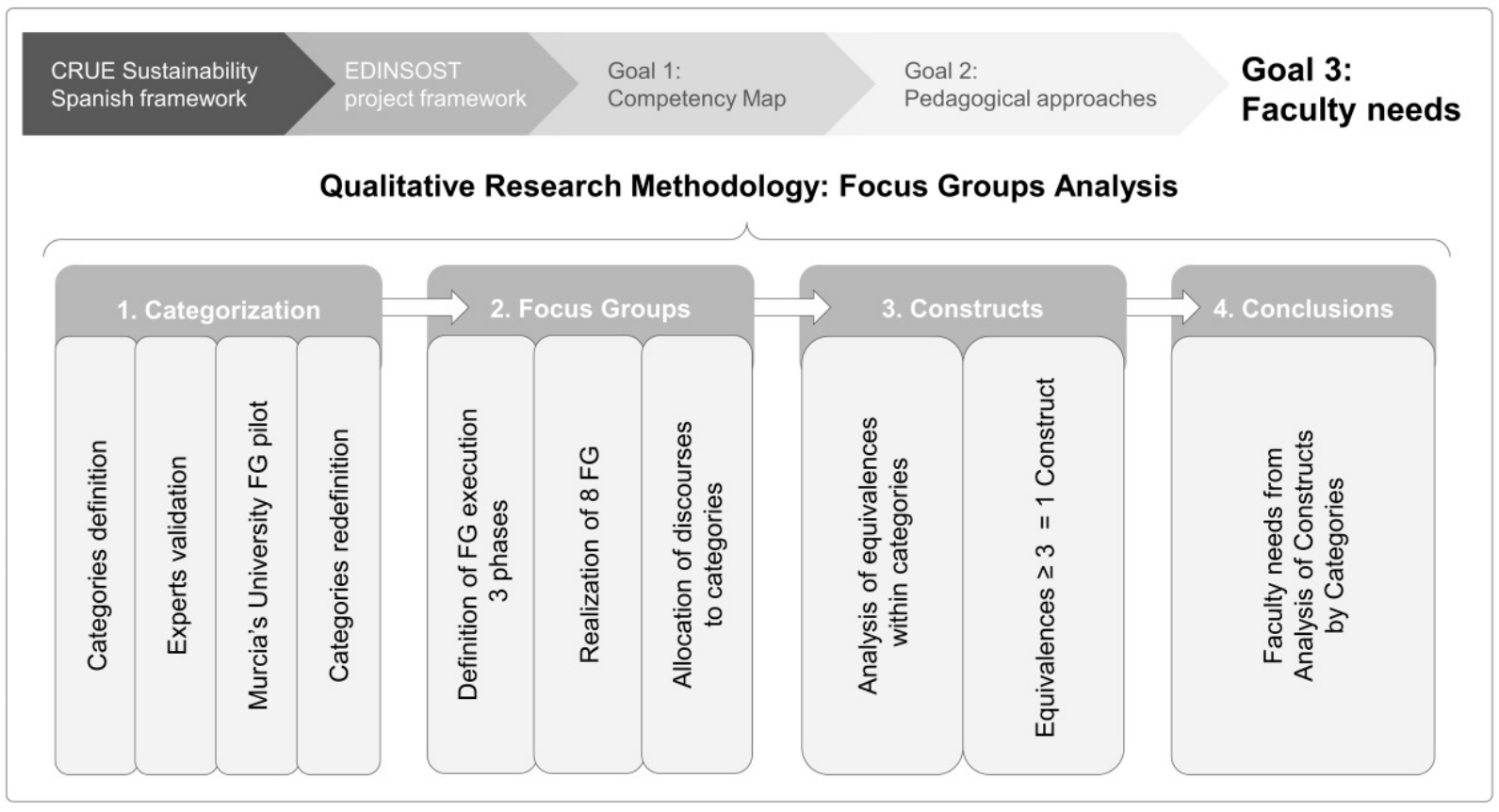

Figure 1. Research methodology.

\subsubsection{Category System Development}

The category system (see Table 1) was developed through a participatory approach involving all the researchers of the 10 universities participating in the project. This gave rise to the first self-validation process when devising the category system as an instrument. 
Table 1. Category System. Source: EDINSOST Project.

\begin{tabular}{|c|c|c|}
\hline Category & Description & Code \\
\hline $\begin{array}{l}\text { Conception of } \\
\text { Sustainability }\end{array}$ & $\begin{array}{l}\text { This category gathered answers or statements regarding how } \\
\text { sustainability was understood. Scores included: Level } 0 \text { (no } \\
\text { relation among its dimensions), level } 1 \text { (knowledge), level } 2 \\
\text { (know-how), level } 3 \text { (demonstrate + apply) [42]. }\end{array}$ & CS \\
\hline $\begin{array}{l}\text { The Importance of } \\
\text { Sustainability }\end{array}$ & $\begin{array}{l}\text { This category was selected for statements that mentioned } \\
\text { somehow the importance of sustainability at any sphere } \\
\text { (academic, personal, professional, social transformation ... ). }\end{array}$ & IS \\
\hline Participation & $\begin{array}{l}\text { Statements referring to the participation in projects or programs } \\
\text { (previously, currently, intended to or never participated) and } \\
\text { those pointing out possible obstacles because of which } \\
\text { participation was null. }\end{array}$ & PA \\
\hline Ethical Models & $\begin{array}{l}\text { Statements selected when referring to personal and professional } \\
\text { codes of conduct oriented towards generating sustainability } \\
\text { awareness and values. }\end{array}$ & $\mathrm{ME}$ \\
\hline Courses & $\begin{array}{l}\text { This category drew statements regarding which university } \\
\text { courses faculty incorporated sustainability the most. }\end{array}$ & AS \\
\hline $\begin{array}{l}\text { Pedagogical } \\
\text { Strategies }\end{array}$ & $\begin{array}{l}\text { Statements and observations on the use and effectiveness of } \\
\text { several pedagogical strategies. }\end{array}$ & ED \\
\hline $\begin{array}{l}\text { Sustainability } \\
\text { competencies }\end{array}$ & $\begin{array}{l}\text { Remarks about which competencies were considered the most } \\
\text { important in the training of future professionals. }\end{array}$ & CCS \\
\hline $\begin{array}{l}\text { Roles, relationships } \\
\text { and class } \\
\text { environment }\end{array}$ & $\begin{array}{l}\text { This category filtered for statements referring to professor and } \\
\text { student roles, which relationship and social environment within } \\
\text { a class was considered to be best to encourage sustainability to } \\
\text { be addressed, or those that aided the most in incorporating } \\
\text { sustainability competencies. }\end{array}$ & RRC \\
\hline $\begin{array}{l}\text { Self } \\
\text {-Evaluation }\end{array}$ & $\begin{array}{l}\text { Statements regarding the degree of effectiveness and efficiency } \\
\text { in the implementation of resources. }\end{array}$ & $\mathrm{AE}$ \\
\hline
\end{tabular}

The authors used the results of objective 1 on the EDINSOST competencies map, by Sánchez-Carracedo et al. [42], the SDE teaching strategies proposed by Tejedor et al. [43] and the results of objective 2 as references for the development of the category system.

A second validation process was carried out, generating a focus group with the University of Murcia's faculty as a pilot study, who did not participate in the project to avoid bias in the results.

\subsubsection{Design and Conducting of the Focus Groups}

A focus group is defined by Williams and Katz [44] as a small gathering of individuals who have a common interest or characteristic, assembled by a moderator, who uses the group and its interactions as a way to gain information about a particular issue. One of the most useful tools to plan focus groups for educators was conceived by Einsiedel et al. [45], and based on this, the authors designed the present focus group approach in 3 phases.

Phase 1: Participant recruitment.

Before the formation of the focus groups, the EDINSOST project designed and executed a questionnaire to university faculty members on the degrees and universities involved, which yielded 858 responses. All faculty staff who responded to the questionnaire were invited to participate in the focus groups, taking into account gender and discipline balance. This selection process ended with 8 focus groups at six universities covering all areas of study. Each focus group was established to range from five to nine participants.

Phase 2: Conducting the Focus group.

The focus groups were comprised of three stages, with a total duration of $90 \mathrm{~min}$ : introduction, development and conclusion. 
Phase 2.1: Introduction (15 min)

The moderator presented the participants and briefly explained the focus group's objective. Participants were then asked to respond in a single phrase how they understood sustainability.

Phase 2.2: Development (65 min).

The moderator presented previous EDINSOST questionnaire results to obtain information regarding the university faculty's knowledge on sustainability in three aspects: competencies, pedagogical strategies and practical coursework in the classroom. The moderator did not intervene, except in cases when the discussion deviated from the topic. The moderator observed and took notes, making sure that all the objectives of the focus group were addressed.

To deepen the discourses on each aspect, the following questions were posed during the focus group:

Competencies Section

- Which aspects are essential in the education for sustainability, and to which degree are they present in the disciplines?

- Which competencies should university faculty members attain in order to address these aspects effectively?

- These are the results of the questionnaire administered on (date). What is your opinion regarding the results? Did any of the results surprise you?

- Which opportunities and limitations do the faculty face addressing sustainability? How could opportunities be seized and limitations overcome?

- Do you think university faculty staff have enough (quality) resources and training opportunities to adequately train undergraduates on sustainability? Which training could motivate faculty staff and help improve their competencies in sustainability?

Pedagogical Strategies Section

- Which pedagogical strategies do you consider suitable to train students in sustainability? Which have been effective? What other ideas could work?

- What should a pedagogical method take into account to enable learning sustainability competencies?

- Which procedures and resources do you know to introduce the sustainability perspective in a discipline?

- What is your opinion about the questionnaire's results?

Good Practices Section

How can practical or lab sessions improve sustainability learning?

Phase 2.3: Conclusions (10 min)

The moderator intervened to deepen and conclude on the ideas that emerged in the group.

Phase 3: Transcription

The focus group sessions were recorded in audio and/or video formats and transcribed to the qualitative data analysis software.

\subsubsection{Focus Groups Coding}

A total of eight focus groups were conducted (see Table 2).

Table 2. Focus groups conducted.

\begin{tabular}{cccccc}
\hline \multirow{2}{*}{ University } & ID & Subject Area & Sub-Area & \multicolumn{2}{c}{$\begin{array}{c}\text { Number of Participants } \\
\text { per Gender }\end{array}$} \\
\cline { 4 - 6 } & & & & $\mathbf{M}$ & $\mathbf{F}$ \\
\hline UPC & UPC-GF1 & Engineering & Industrial & 5 & 2 \\
\hline UPC & UPC-GF2 & Engineering & Civil and Architecture & 4 & 4 \\
\hline UPM & UPM-GF1 & Engineering & ICTs & 4 & 2 \\
\hline
\end{tabular}


Table 2. Cont.

\begin{tabular}{|c|c|c|c|c|c|}
\hline \multirow[t]{2}{*}{ University } & \multirow{2}{*}{ ID } & \multirow{2}{*}{ Subject Area } & \multirow{2}{*}{ Sub-Area } & \multicolumn{2}{|c|}{$\begin{array}{c}\text { Number of Participants } \\
\text { per Gender }\end{array}$} \\
\hline & & & & $\mathbf{M}$ & $F$ \\
\hline US & US-GF1 & Education & & 5 & 0 \\
\hline $\mathrm{UCO}$ & UCO-GF1 & $\begin{array}{l}\text { Environmental } \\
\text { Science }\end{array}$ & & 1 & 6 \\
\hline UIC & UIC-GF1 & Education & & 2 & 6 \\
\hline UIC & UIC-GF2 & $\begin{array}{l}\text { Business Ad- } \\
\text { ministration }\end{array}$ & & 4 & 1 \\
\hline \multirow[t]{2}{*}{ UM } & UM-GF1 & $\begin{array}{l}\text { Business Ad- } \\
\text { ministration }\end{array}$ & & 5 & 4 \\
\hline & & & Total & 30 & 24 \\
\hline
\end{tabular}

A participant information table (see Table 3) was generated for each focus group, describing the participants' identity and background in order to characterise the sample, aiming for gender balance.

Table 3. Example of a focus group participant information table (* to protect respondents confidentiality, real names are not shown).

\begin{tabular}{|c|c|c|c|c|c|c|}
\hline Group & UPC-GF1 & Number of Participants & 8 & Moderator & \multicolumn{2}{|c|}{ Moderator 1} \\
\hline Date & 2 May 2018 & Start time & $10: 15$ & End time & & 50 \\
\hline \multirow{2}{*}{ Name } & \multirow{2}{*}{ Gender } & \multirow{2}{*}{\multicolumn{3}{|c|}{ Title/Teaching subarea }} & \multicolumn{2}{|c|}{ Disciplines } \\
\hline & & & & & Core & Applied \\
\hline Participant A* & $\mathrm{F}$ & Engineer/Envir & ering & & $x$ & \\
\hline Participant B & M & Architect/Architect & chnolo & & $x$ & $x$ \\
\hline Participant C & $\mathrm{F}$ & Architectural Technologist/Bachelo & /Maste & ustainability & $x$ & $x$ \\
\hline Participant D & M & Arch & & & $x$ & $x$ \\
\hline Participant E & M & Architectural Tech & cuction & & & $x$ \\
\hline Participant F & M & Arch & & & $x$ & \\
\hline Participant G & $\mathrm{F}$ & Environmental Sciences Ph.D./ & ig and & Works & & $x$ \\
\hline Participant H & $\mathrm{F}$ & Geogr & & & & \\
\hline
\end{tabular}

\subsubsection{Triangulation and Construct Design}

The authors designed Table 4 to gather the focus group field data. Subsequently, we followed an internal intramethod triangulation protocol by which the data gathered was first randomly interchanged among the researchers of each university, then the resear-chers analysed the other university's units of information and finally all the analysed results were shared in meetings as a means of consolidating the analysis procedures.

Each university was responsible for transcribing its focus group data, following Table 4's format, where the "sequence" column indicates the order of appearance in the focus group; the "timestamp" columns" "minute" and "duration" allow for easy location of the speech in the recording; the "participant" column list shows those who made a contribution to the focus group; the "information unit" is the smallest fragment chosen that retains relevant meaning in itself, which is finally sorted into the "category" column. The authors deemed it important to assign the information unit to a maximum of two 
categories because relating data to several categories would have decreased the rigor of the data and deterred the research process.

Table 4. Focus group transcription.

\begin{tabular}{|c|c|c|c|c|c|}
\hline \multirow{2}{*}{ Sequence } & \multicolumn{2}{|c|}{ Timestamp } & \multirow{2}{*}{ Participant } & \multirow{2}{*}{ Information Unit } & \multirow{2}{*}{ Category } \\
\hline & Minute & Duration & & & \\
\hline 1 & 4:06-4:19 & $13^{\prime \prime}$ & S1 & $\begin{array}{l}\text { I am completely unclear about sustainability as a concept, I mean: we } \\
\text { have always been told that we have to educate for sustainability, ... }\end{array}$ & CS \\
\hline 2 & $4: 36-4: 43$ & $17^{\prime \prime}$ & S1 & $\begin{array}{l}\text { Sustainability is everywhere. It shows up in many speeches, on TV; it is } \\
\text { something that everyone says: yes, yes, we have to be sustainable. }\end{array}$ & IS \\
\hline 3 & $5: 03-5: 11$ & $8^{\prime \prime}$ & S1 & $\begin{array}{l}\text { How can we teach about sustainability if the planet is currently } \\
\text { unsustainable? We consume many more resources than what the planet } \\
\text { can bear. }\end{array}$ & $\mathrm{ME}$ \\
\hline
\end{tabular}

Once the 8 focus groups were transcribed, the authors developed each category construct based on the transcript analysis. To do so, the most significant units of information were selected by associating them with the categories, in such a way that as it appears in Tables 4 and 5, a construct was generated as a result of the coincidence between units of information from at least three focus groups; we call this the triangulation process. It occurs between different focus groups and also between different people within the same focus group [46]. Constructs enable the further development of a more abstract discourse closer to a theorical entity, with the objective of reaching global, structured and systematic knowledge [46,47].

Table 5. Example of a construct in relation to the "Importance of Sustainability" category. Source: EDINSOST Project design.

\begin{tabular}{|c|c|c|}
\hline \multicolumn{3}{|c|}{$\begin{array}{l}\text { The Importance of Sustainability (2) } \\
\text { Statements Regarding the Importance of Sustainability (Be It Little to Very Important) in All Its Spheres (Academic, Personal, Professional, } \\
\text { Social Transformation ... ) }\end{array}$} \\
\hline Identification Key & Construct content & Sources \\
\hline $\mathrm{Co} 2: 1$ & $\begin{array}{l}\text { Sustainability is very important in all degrees, despite being more evident in some. } \\
\text { I think of it in science and environmental sciences, but also for lawyers. } \\
\text { Sustainability not only in environmental sciences, but in all. It must be present in all degrees. } \\
\text { Last-year Research Project in sustainability. There is awareness. There is interest. } \\
\text { Sustainability is super important in our degrees. }\end{array}$ & $\begin{array}{l}\text { GF1-UCO31S6; } \\
\text { GF1-UCO60S4; } \\
\text { GF1-UIC28S1; } \\
\text { GF1-UMU61S3 (and all) }\end{array}$ \\
\hline $\mathrm{Co} 2: 2$ & $\begin{array}{l}\text { It is necessary and important to incorporate sustainability in the University. } \\
\text { It is necessary and important. } \\
\text { More present in society, the University has a great task and responsibility. } \\
\text { The issue is on the streets, it is necessary to incorporate it in teaching. } \\
\text { It is important to really apply it, I have been hearing about everyone incorporating it for } 20 \text { years. } \\
\text { Students ask for sustainability learning. } \\
\text { It is important to be trained on sustainability and also on values. } \\
\text { Sustainability has to be ubiquitous in everything we do. } \\
\text { Sustainability will show up everywhere, it is trendy. }\end{array}$ & $\begin{array}{l}\text { GF1-UMU53S3; } \\
\text { GF2-UIC5S5; } \\
\text { GF1-UPC12S4; } \\
\text { GF1-UPC13S3; } \\
\text { GF1-UPC20S5; } \\
\text { GF1-UPM8S3; } \\
\text { GF1-US8S2; } \\
\text { GF1-US10S3 }\end{array}$ \\
\hline $\mathrm{Co} 2: 3$ & $\begin{array}{l}\text { Given its importance, taking sustainability into consideration has to be mandatory. } \\
\text { Unfortunately, it has to be by force, make it mandatory. } \\
\text { It should be obligatory. } \\
\text { It currently suffers from being voluntary. } \\
\text { Most professors have not even considered it. }\end{array}$ & $\begin{array}{l}\text { GF1-UPC26S2; } \\
\text { GF1-UPC48S5; } \\
\text { GF1-UPC49S7; } \\
\text { GF1-UMU33S2 }\end{array}$ \\
\hline $\mathrm{Co} 2: 4$ & $\begin{array}{l}\text { Sustainability has to be implemented cross-wise through all curri-cula. } \\
\text { Sustainability as a general competency and in a cross-wise mode. } \\
\text { Sustainability, in general, are cross-wise topics. } \\
\text { A dash in every course. }\end{array}$ & $\begin{array}{l}\text { GF1-US10S3; } \\
\text { GF1-UMU45S1; } \\
\text { GF1-UMU46S2 }\end{array}$ \\
\hline $\mathrm{Co} 2: 5$ & $\begin{array}{l}\text { Sustainability is not considered relevant in some areas. } \\
\text { The professor responsible for the last-year research project does not even care about the } \\
\text { environment. } \\
\text { Sustainability in construction is almost incompatible. }\end{array}$ & $\begin{array}{l}\text { GF1-UPC18S4; } \\
\text { GF1-UPC3S4 }\end{array}$ \\
\hline
\end{tabular}


These constructs were organised in tables (Table 5), in which the first column assigned an identification key to each, such as Co5:1, where "Co" is the abbreviation of the word "construct", followed by the category number " 5 ", and the number after the colon indicates the order. The second column contained the construct content, and the third column listed the focus groups that were the sources for each construct (e.g., GF1-UCO).

The construct outlining process involves detecting a common discourse among at least three participants of one or more focus groups, including from other universities. The discussion and conclusions below are drawn from this.

\section{Results}

The most relevant ideas and contributions derived from the focus groups are presented in this section. As explained above, the constructs drawn from the focus groups enabled the research problems posed to be addressed.

The authors first present the quantitative results: the number of information units identified for each category, the number of groups and the degrees from which they were drawn (Table 6). Such data were useful to discover the aspects that most worry university professors and those that are most relevant to them. It was observed that the university faculty training and the pedagogical strategies had dominated the discussion in the groups. On the other hand, other categories did not draw as much interest, even though they had been considered relevant to the integration of sustainability competencies in higher education $[48,49]$.

Table 6. Quantitative analysis of all focus groups categories. (EDU-Education degrees; ENV-Environmental degrees; ENG-Engineering degrees).

\begin{tabular}{|c|c|c|c|c|}
\hline Category & Information Units & Constructs & Different GF & Degrees \\
\hline Faculty training & 77 & 5 & All & All \\
\hline Pedagogical strategies & 62 & 6 & All & All \\
\hline Good Practices & 32 & 5 & 6 & All \\
\hline Curriculum organisation & 29 & 3 & 5 & All \\
\hline Faculty motivation and commitment & 26 & 2 & 7 & All \\
\hline The conception of Sustainability & 25 & 4 & All & All \\
\hline Ethical models & 24 & 4 & All & All \\
\hline The importance of sustainability & 19 & 4 & 7 & All \\
\hline Roles, relationships and classroom environment & 18 & 3 & 6 & EDU, GADE, ENG \\
\hline Sustainability competencies & 16 & 2 & 3 & ENV, EDU, ENG \\
\hline Institutional support & 15 & 5 & 4 & ENV, EDU, ENG \\
\hline Courses & 15 & 2 & 6 & All \\
\hline Holistic view & 14 & 2 & All & All \\
\hline Participation & 12 & 2 & 3 & EDU, ENG \\
\hline Level of cross-wise presence and coordination & 4 & 1 & 1 & ENV \\
\hline Exposition teaching & 2 & 0 & 2 & ENV, EDU \\
\hline Self-evaluation & 1 & 0 & 1 & EDU \\
\hline University and society & 0 & 0 & 0 & - \\
\hline Student off-campus learning & 0 & 0 & 0 & - \\
\hline
\end{tabular}

The constructs generated were grouped into categories according to how they related to the research questions in order to enhance discussion. The quotations shown in this section are followed by the focus group in which they were stated in parentheses. 
Regarding the first research question about the conceptions professors have of sustainability in the context of the Spanish higher education system, there were statements about the concept, the importance of sustainability in university education and about ethical models (Table 6).

Most frequently, the professors' concept of sustainability did not include all its dimensions (Co1:3); the environmental dimension was the one that was always mentioned: "when I hear 'sustainability', I relate it to environment" (GF1-UMU1S1). Nevertheless, in six groups comprising all university degrees, there were statements that indeed reflected a sustainability concept that integrated the three basic dimensions (Co1:1): "Sustainability is the balance between economy, society and the environment" (GF1-UCO1S1). Constructs considering future generations (Co1:2) and correct resource use (Co1:4) appeared less frequently.

A construct that came forth in all the groups and with great frequency (14 information units) was the idea that decisions and measures related to sustainability are ethical rather technological questions (Co4:1). This is emphasised by the relevance of professors as role models: "from the moment we say we care about the future generations, it is an ethical question" (Co4:2), "[ . . . ] education for professional responsibility, taking on as responsible for the impact on the environment, people, the economy that your decisions can cause" (Co4:3), "it is important that university faculty are aware of the educational impact of their behaviour" (Co4:5).

In all except one group, the importance of sustainability in university education was discussed. The most frequent information units considered it necessary and important to incorporate sustainability into the university (Co2:1): "Education in sustainability and values is important" (GF1-UPM8S3). Other constructs that arose were the importance of implementing sustainability in all the degrees (Co2:2), to make its inclusion mandatory (Co2:3) and a cross-wise approach among courses (Co2:4).

Regarding the second research question about the sustainability competencies university faculty in Spain have, Table 6 shows that the topic on faculty training is the one with the most information units. The category of faculty motivation and commitment was also relevant.

Information units with reference to the need for training to convey sustainability competencies in teaching were identified in all groups (Co11:1): "It is necessary to provide professors with the tools to enable teaching, to have pedagogical resources and develop sustainability in class" (Co11:2), "Practical training is missing" (Co11:2), "Specific training is missing, course specific and interdisciplinary, to present a holistic view of sustainability" (Co11:2). Comments on the need for training in sustainability competencies such as critical judgment, systemic views or ethical principles (Co11:3) were less frequent.

Responses on the university faculty's lack of awareness and responses about the importance of including sustainability in university education were also very frequent (in seven groups, spanning all degrees): "Many professors (especially engineers) have been trained in the paradigm of ruling projects, with no sensitivity towards environmental issues" (Co5:1). Education was considered an essential factor to promote greater awareness, motivation and commitment among professors ("Training leads to awareness" (Co5:3)).

Finally, it is worth highlighting that in three groups, carrying out the focus group was considered an educational experience in itself because of the effect of a "shared reflection" among participants.

In relation to the third research question, the way in which pedagogical strategies for sustainability are implemented, the category Pedagogical Strategies was the second in frequency and the one which had the greatest number of constructs. No construct was possible in the Exposition Teaching category (Table 6).

The construct with the greatest number of information units refers to those promoting the contact with reality and critical pondering, bringing forward a global and holistic view of sustainability, advocating student implication, and those attractive both to students and professors: "real situations deeply change people" (GF2-UIC61); "boost a critical attitude [ ... ] you have to make your students debrief, question themselves" (GF1-US33S1). This coincides with 
the work carried out by researchers that emphasised the importance of teacher training and teaching strategies for the implementation of sustainability $[43,46,50]$.

As a concrete strategy, learning based on projects and on problems or cases was emphasised in all degrees. According to the participating faculty, by using learning methods based on projects, students can evaluate their impact on several scopes of sustainability and redirect project design based on impact, choosing the most sustainable alternative. Useful aspects to take into account are: pose questions that promote pondering; bolster collaborative work between students and professors; and, as much as possible, propose interdisciplinary projects and implement this work dynamic in projects throughout the years of the degree course, particularly in the last-year Research Project. Additionally, within project learning, service-learning was considered to be a particularly effective strategy for the development of sustainability competencies: "it not only requires student implication in the course, in the course subject, but also in the context itself they will engage in, to be able to address the issue and the previously detected needs" (GF1-US44S3).

On the other hand, learning based on problems, case analysis or debates about real situations were also deemed very appropriate to train individuals in sustainability competencies. These strategies bridge the gap of real situations with classroom work in a more feasible way than through projects. Respondents pointed out that conflicting complex situations should be chosen to develop decision making ability based on sustainability criteria. Taking cases and problems on which professors had worked or work at present was also regarded as a positive. "It is very effective to put them in antagonist situations. Contrast, debate and moral dilemmas when facing a given situation" (GF2-UPC22); "the problem (strategy) has worked fine with me: to present a complex problem to students and see how they can solve it, within some established parameters, those given in the 2030 agenda, which they have to read ahead of time" (GF1-UMU73).

Moreover, it was also possible to identify constructs related to the barriers encountered when using appropriate pedagogical strategies and during evaluation. In all focus groups except one, difficulties using appropriate pedagogical strategies were mentioned. They coincide with the obstacles presented in other investigations $[13,17,34,46]$. These difficulties included university faculty training deficiencies and students' lack of habit and motivation: "These pedagogical strategies are unknown" (GF1-UMU13); "They react as they are not used to face these types of questions [real global problems analysis]" (GF1-US26S5); "the energy problem is posed first, but they see it as a burden and want to get to the calculations and quantify, but they are not interested" (GF1-UPM54S1). Other factors from the academic context identified were the student ratio per classroom and the classroom structure, study plans with excessive work load and the lack of institutional support and recognition: "all these strategies that the Education Institutes, Bolonia process, boast, I think are appropriate, but neither the study plan is designed to integrate these initiatives, nor you get the support to implement them, because every time you try to do anything like this, it is very difficult" (GF1-UPC35).

With regard to the evaluation in terms of sustainability competencies learned, strategies alternative to exams were proposed in an Engineering and a Business Administration focus group. Essays presenting results or reflecting about what was learned were examples. The need for procedures and rubrics to ease evaluation was also noted.

The last research question addressed how the practical coursework in sustainability in the Spanish university context is related to categories such as curriculum organization, good practices and institutional support, to mention the ones which had the greater amount of information units.

As far as curriculum organization is concerned, the absence of teaching guides and study plans on sustainability was mentioned in focus groups of all degrees (Co11:1), although professors expressed their willingness to complete them (Co7:1). Several reasons were discerned: difficulty in incorporating them due to the type of the course, lack of practice in developing competencies cross-wise (which usually depends solely on the will of professors), the prevalence of technical content as opposed to social and environmental content (in the case of Engineering), or the fact that study plan design is based more on the 
faculty's capacity and interests rather than on social needs. The rigidity of the study plans was deemed a substantial deterrent, given that they are structured in courses, in lectures and practical coursework, and with a hierarchical model that makes interdisciplinarity unviable $[42,46]$. To counter this, project-oriented work was proposed as an alternative (Co10:2) with a suggestion that professors bring forth in class "a wider view beyond their subject, conveying a more global and integral view of education" (GF1-UPM50S3).

Despite all previous hindrances, there were examples of courses in all kinds of degrees that explicitly work on sustainability competencies from a holistic perspective. This was most evident in Environmental Sciences, which includes core and optional courses including "Sustainability" in the 4th year. Sustainability competencies are addressed in the Engineering degrees in courses such as "Accessibility and sustainability," "Science, technology and Society" and in the last-year Research Project. In Business Administration, the projects on the course "Marketing" require sustainability objectives to be included. The course "City and Citizenship" in the Education degree of the US was also mentioned.

As regards the classroom environment and good practices that are considered most beneficial, (especially in the Education focus groups) the coherence of the habits of faculty in the classroom as regards the knowledge and messages transmitted were highlighted: "We need to first be aware, we need to reach the expertise, we need to get these habits" (GF2-UIC24). Environmental good practices appeared the most, although in relation to distinct aspects: the use of paper, heating, car or habits in the laboratory (Co16:5). In some groups, the importance of making explicit the reason for engaging in sustainable action and how to specify sustainable action (Co16:4) were highlighted. Some doubts were also made known as to which are the most adequate practices (in aspects such as inclusion and paper use) and infrastructure-prone difficulties (Co16:3).

Furthermore, it was regarded as relevant (in half of the focus groups and particularly in those of Education) that professors assume the role of facilitator of learning experiences that need to be built together. This involves the creation of a participatory environment and an environment of critical reflection and autonomy amongst the students, including the evaluation activities.

Finally, several constructs were identified regarding the importance of institutional support. In terms of embedding sustainability in the curriculum, institutional support was regarded as fundamental for sustainability work experiences to be no longer anecdotical, but to be instead incorporated throughout the degrees. Moreover, from the institution perspective, it was deemed necessary to increase the coordination among professors in relation to their awareness and training. The need for incentives for those willing to integrate sustainability in the study plan was additionally pressed, as had been completed, for instance, for teaching in other languages. Ultimately, respondents thought that sustainability should be established as a strategic matter in the university, related to the devising of integrative plans and making them visible. This would promote the coherence mentioned above, setting an example as an institution and advancing good practices in aspects such as attention to diversity and sustainable daily habits.

\section{Conclusions}

In the present research, the authors presented a methodological approach to analyse university faculty understanding, motivations and difficulties related to the inclusion of sustainability education in their teaching. Our approach included focus groups and the definition of a categorization system to analyse discourses in relation to sustainability education.

Most university faculty highlighted the importance of sustainability in higher education. Nevertheless, some faculty still mainly addressed the environmental dimension and did not consider the social or economic dimensions as much.

In addition, in the holistic conception of sustainability, it seems important to also make visible the ethical dimension that underpins it, integrating training in sustainability within the framework of professional responsibility in relation to the impacts of its activity. 
Practical student-centred pedagogical strategies proved to be the most effective to train individuals in sustainability, such as service learning, project-based learning and challenge-based learning. However, professors need training on how to apply those strategies efficiently and effectively, especially when dealing with curricula already full with other competencies.

In addition to training in teaching methodologies, it is important for teachers to be more aware of the importance of integrating sustainability in university training and to commit to it. However, this commitment cannot be merely individual, it must be accompanied by a clear institutional commitment that could be implemented in the following directions:

- Ensure curriculum schemes in which sustainability training is explicit in all degrees by means of compulsory competencies and specific courses on sustainability;

- Provide training for university faculty in sustainability competencies and pedagogical approaches for sustainability;

- Promote spaces for discussion, reflection and the joint work of teachers, in such a way that their awareness and motivation are enhanced.

The most essential and challenging catalyser for embedding sustainability in higher education is to include the requirement of sustainability learning outcomes in the accreditation of degrees, and of sustainability competencies in the university faculty's accreditation for their academic careers.

\subsection{Limitations of This Work}

The present work is not without limitations, which mainly come from the sample itself: eight focus groups, some of them with few (five) teachers. However, taking into account the range of disciplines covered (Education, Engineering, Environmental Sciences and Business Administration) which are closely related to the different dimensions (environmental, social and economic) of sustainability, we consider that the limitations that can be derived from the sample size are overcome by the diversity of points of view collected and their qualitative value.

\subsection{Future Research Directions}

The EDINSOST2 project: Integration of sustainable development goals into sustainability training in Spanish university degrees, in which the importance of teacher training is deepened, to facilitate and promote a more explicit and coherent integration of sustainability competencies in the study plans.

Author Contributions: Conceptualization, J.S. and P.B.; methodology, J.R.-M.; software, J.R.-M.; validation, J.S., R.M. and A.G.; formal analysis, S.A.-T.; investigation, P.B.; resources, R.M.; data curation, M.A.; writing—original draft preparation, A.G.; writing—review and editing, P.B.; supervision, J.S.; project administration, J.S.; funding acquisition, all. All authors have read and agreed to the published version of the manuscript.

Funding: This research was funded by the Spanish Ministry of Economy, Industry and Competitiveness under contract EDU2015-65574-R.

Acknowledgments: This work has been financed by the Spanish Ministry of Economy, Industry and Competitiveness under contract EDU2015-65574-R.

Conflicts of Interest: The authors declare no conflict of interest. The funders had no role in the design of the study; in the collection, analyses, or interpretation of data; in the writing of the manuscript, or in the decision to publish the results. 


\section{References}

1. UN. Objetivos de Desarrollo del Milenio. Informe 2015. Available online: http://www.un.org/es/millenniumgoals/pdf/2015 /mdg-report-2015_spanish.pdf (accessed on 16 December 2020).

2. SDSN Australia/Pacific. Getting Started with the SDGs in Universities: A Guide for Universities, Higher Education Institutions, and the Academic Sector. Australia, New Zealand and Pacific Edition. Sustainable Development Solutions NetworkAustralia/Pacific, Melbourne. Available online: https://ap-unsdsn.org/wp-content/uploads/2017/08/University-SDG-Guide_ web.pdf (accessed on 17 December 2020).

3. UN. Transforming our World: The 2030 Agenda for Sustainable Development. 2015. Available online: https://undocs.org/en/ A/RES/70/1 (accessed on 17 March 2021).

4. IPCC. Climate Change 2014: Synthesis Report. Contribution of Working Groups I, II and III to the Fifth Assessment Report of the Intergovernmental Panel on Climate Change; Core Writing Team, Pachauri, R.K., Meyer, L.A., Eds.; IPCC: Geneva, Switzerland, 2015. Available online: https://www.ipcc.ch/site/assets/uploads/2018/05/SYR_AR5_FINAL_full_wcover.pdf (accessed on 17 December 2020).

5. IPCC; Masson-Delmotte, V.; Zhai, P.; Pörtner, H.O.; Roberts, D.; Skea, J.; Shukla, P.R.; Connors, S. Summary for Policymakers. Global Warming of, $1.5^{\circ} \mathrm{C}$ 2018. Available online: https://report.ipcc.ch/sr15/pdf/sr15_spm_final.pdf (accessed on 17 December 2020).

6. Gil-Pérez, D.; Vilches, A.; Toscano, J.C.; Macías, O. Década de la Educación para un Futuro Sostenible (2005-2014): Un punto de inflexión necesario en la atención a la situación del planeta. Rev. Iberoam. Educ. 2006, 40, 125-178.

7. UNESCO. Roadmap for Implementing the Global Action Programme on Education for Sustainable Development. 2014. Available online: http:/ / unesdoc.unesco.org/images/0023/002305/230514e.pdf (accessed on 17 December 2020).

8. UNESCO. Education for Sustainable Development Goals. Learning Objectives. UNESCO, Paris. 2017. Available online: http:/ / unesdoc.unesco.org/images/0024/002474/247444e.pdf (accessed on 16 December 2020).

9. COPERNICUS Alliance. The Rio+20 Treaty on Higher Education, COPERNICUS Alliance. European Network on Higher Education for Sustainable Development. Registered NGO under German law Registration Number: VR200489. Available online: https://www.copernicus-alliance.org/images/Documents/treaty_rio.pdf (accessed on 16 December 2020).

10. Benayas, J.; Alba, D.; Sánchez, S. La ambientalización de los campus universitarios: El caso de la Universidad Autónoma de Madrid. Ecosistemas 2002, 11.

11. Tilbury, D. Education for Sustainable Development: An Expert Review of Processes and Learning; Available in Spanish, French and English.ED-2010/WS/46; UNESCO: Paris, France, 2011.

12. Albareda-Tiana, S.; Vidal-Raméntol, S.; Fernández-Morilla, M. Implementing the Sustainable Development Goals at University level. Int. J. Sustain. High. Educ. 2018, 19, 473-497. [CrossRef]

13. Aznar Minguet, P.; Ull, M.A.; Martínez-Agut, M.P.; Piñero, A. Informe de investigación: Evaluación de la Introducción de Competencias Generales Para la Sostenibilidad en los Estudios de Grado de la Universitat de València. 2013. Available online: http:/ / www.uv.es/fatwireed/userfiles/file/INFORME_COMPETENCIAS_GENERALES_GRADOS_CON_PROTECCION_ DATOS[1].pdf (accessed on 16 December 2020).

14. Aznar Minguet, P.; Ull, M.A.; Piñero, A.; Martínez-Agut, M.P. La sostenibilidad en la formación universitaria: Desafíos y oportunidades. Educ. XXI 2014, 17, 131-158. [CrossRef]

15. Benayas, J.; Alba, D. Evolución y tendencias de la incorporación de la sostenibilidad en las universidades españolas. In Visiones y Experiencias Iberoamericanas de Sostenibilidad en las Universidades; Universidade de Sâo Paulo: Sâo Paulo, Brazil, 2011; pp. 29-35.

16. Ferrer-Balas, D.; Lozano, R.; Huisingh, D.; Buckland, H.; Ysern, P.; Zilahy, G. Going beyond the rhetoric: System-wide changes in universities for sustainable societies. J. Clean. Prod. 2010, 18, 607-610. [CrossRef]

17. Fuertes, M.T.; Albareda Tiana, S. Evaluación de competencias genéricas en sostenibilidad y responsabilidad social universitaria. In Experiencia en Docencia Superior; ACCI Ediciones: Madrid, Spain, 2014; pp. 141-159. ISBN 978-84-5705-3-0.

18. Geli de Ciurana, A.M.; Leal Filho, W. Education for sustainability in university studies: Experiences from a project involving European and Latin American universities. Int. J. Sustain. High. Educ. 2006, 7, 81-93. [CrossRef]

19. Leal Filho, W.; Manolas, E.; Pace, P. The Future We Want: Key issues on sustainable development in higher education after Rio and the UN decade of education for sustainable development. Int. J. Sustain. High. Educ. 2015, 16, 112-129. [CrossRef]

20. Lozano, R. Diffusion of sustainable development in universities' curricula: An empirical example from Cardiff University. J. Clean. Prod. 2010, 18, 637-644. [CrossRef]

21. Lozano, R. The state of sustainability reporting in universities. Int. J. Sustain. High. Educ. 2011, 12, 67-78. [CrossRef]

22. Murga-Menoyo, M.A. Competencias para el desarrollo sostenible: Las capacidades, actitudes y valores meta de la educación en el marco de la Agenda global post-2015. Foro Educ. 2015, 13, 55-83. [CrossRef]

23. Bertschy, F.; Künzli, C.; Lehmann, M. Teachers' Competencies for the Implementation of Educational Offers in the Field of Education for Sustainable Development. Sustainability 2013, 5, 5067-5080. [CrossRef]

24. Ferreira, J.; Tilbury, D. Higher education and sustainability in Australia: Transforming experiences. In Higher Education in the World, 4, Higher Education's Commitment to Sustainability: From Understanding to Action; GUNI; Palgrave Macmillan: London, UK, 2012; pp. 96-99. ISBN 978-0-230-53555-8.

25. O'Byrne, D.; Dripps, W.; Nicholas, K.A. Teaching and learning sustainability: An assessment of the curriculum content and structure of sustainability degree programs in higher education. Sustain. Sci. 2015, 10, 43-59. [CrossRef] 
26. Ramos, T.B.; Caeiro, S.; van Hoof, B.; Lozano, R.; Huisingh, D.; Ceulemans, K. Experiences from the implementation of sustainable development in higher education institutions: Environmental Management for Sustainable Universities. J. Clean. Prod. 2015, 106, 3-10. [CrossRef]

27. Tilbury, D. Higher education for sustainability: A global overview of commitment and progress. In Higher Education in the World 4: Higher Education's Commitment to Sustainability from Understanding to Action; Palgrave MacMillan: Barcelona, Spain, 2011; pp. 18-28.

28. O'Donoghue, R.; Taylor, J.; Venter, V. How are learning and training environments transforming with ESD? In Issues and Trends in Education for Sustainable Development; Leicht, A., Heiss, J., Byun, W., Eds.; UNESCO Publishing: Paris, France, 2018; pp. 111-131; ISBN 978-92-3-100244-1.

29. GUNI. La educación superior en tiempos de cambio: Nuevas dinámicas para la responsabilidad social. In Elisa Presa González (res.). Humanismo y Trabajo Social; Universidad de León: León, Spain, 2019; Volume 8, pp. 277-281, ISSN 1696-7623.

30. Stephens, J.C.; Graham, A.C. Toward an empirical research agenda for sustainability in higher education: Exploring the transition management framework. J. Clean. Prod. 2010, 18, 611-618. [CrossRef]

31. Antúnez López, M. Problemática del Proceso de Sostenibilización Curricular en el Contexto Universitario Español: La Formación del Profesorado Como Catalizador. Ph.D. Thesis, Universidad de Córdoba, Córdoba, Spain, 2017.

32. Albareda Tiana, S.; Alférez Villarreal, A. A collaborative programme in sustainability and social responsibility. Int. J. Sustain. High. Educ. 2016, 17, 719-736. [CrossRef]

33. Leal Filho, W. About the Role of Universities and Their Contribution to Sustainable Development. High. Educ. Policy 2011, 24, 427-438. [CrossRef]

34. Mas, O. El profesor universitario: Sus competencias y formación. Profr. Rev. Curric. Form. Profr. 2011, 15, 1-17.

35. Rieckmann, M. Learning to Transform the World: Key Competencies in Education for Sustainable Development. In Issues and Trends in Education for Sustainable Development; UNESCO Publication: Paris, France, 2018; pp. 39-59. ISBN 978-92-3-100244-1.

36. Ryan, A.; Tilbury, D. Flexible Pedagogies: New Pedagogical Ideas. Available online: https://www.heacademy.ac.uk/sites/ default/files/resources/npi_report.pdf (accessed on 22 January 2021).

37. Grupo de Sostenibilización Curricular de la CRUE 2009. Página Web del Grupo de Trabajo de Sostenibilización Curricular de la Comisión CRUE-Sostenibilidad. Available online: https://sostecurricularcrue.wordpress.com/about/ (accessed on 16 December 2020).

38. Miñano Rubio, R.; Uribe, D.; Moreno-Romero, A.; Yáñez, S. Embedding sustainability competences into engineering education. The case of informatics engineering and industrial engineering degree programs at Spanish universities. Sustainability 2019, 11, 5832. [CrossRef]

39. Albareda-Tiana, S.; Vidal-Raméntol, S.; Pujol-Valls, M.; Fernández-Morilla, M. Holistic Approaches to Develop Sustainability and Research Competencies in Pre-Service Teacher Training. Sustainability 2018, 10, 3698. [CrossRef]

40. Sánchez-Carracedo, F.; Segalàs, J.; Vidal, E.; Martín, C.; Climent, J.; López, D.; Cabré, J. Improving engineering educators' sustainability competencies by using competency maps. The EDINSOST Project. Int. J. Eng. Educ. 2018, 34, $1527-1537$.

41. CRUE. Directrices para la Introducción de la Sostenibilidad en el Curriculum. Available online: https://www.crue.org/ wpcontent/uploads/2020/02/Directrices_Sosteniblidad_Crue2012.pdf (accessed on 17 December 2020).

42. Sánchez-Carracedo, F.; Ruiz-Morales, J.; Valderrama-Hernández, R.; Muñoz-Rodríguez, J.M.; Gomera, A. Analysis of the presence of sustainability in Higher Education Degrees of the Spanish university system. Stud. High. Educ. 2019, 11, 1-18. [CrossRef]

43. Tejedor, G.; Segalàs, J.; Barrón, A.; Fernández-Morilla, M.; Fuertes, M.T.; Ruiz-Morales, J.; Gutiérrez, I.; García-González, E.; Aramburuzabala, P.; Hernández, A. Didactic Strategies to Promote Competencies in Sustainability. Sustainability 2019, 11, 2086. [CrossRef]

44. Williams, A.; Katz, L. The Use of Focus Group Methodology in Education: Some Theoretical and Practical Considerations. Int. Electron. J. Leadersh. Learn. 2001, 5. Available online: https://journals.library.ualberta.ca/iejll/index.php/iejll/article/view/496i (accessed on 17 December 2020).

45. Einsiedel, A.; Brown, L.; Roos, F. How to Conduct Focus Groups; Extension Press: Saskatoon, SK, Canada; University of Saskatchewan: Saskatchewan, SK, Canada, 1996.

46. Ruiz-Morales, J.; Valderrama-Hernández, R.; Limón-Domínguez, D.; Solís-Espallargas, C. Sustainability and Competency-Based Learning at the University of Seville: Challenges and Opportunities in Educational Sciences. In Integration and Application of Business Graduate and Business Leader Competency-Models; IGI Global: Hershey, PA, USA, 2021; pp. 217-236. [CrossRef]

47. Solis-Espallargas, C.; Ruiz-Morales, J.; Limon-Dominguez, D.; Valderrama-Hernandez, R. Sustainability in the university: A study of its presence in curricula, teachers and students of education. Sustainability 2019, 11, 6620. [CrossRef]

48. Lozano, R.; Merrill, M.Y.; Sammalisto, K.; Ceulemans, K.; Lozano, F.J. Connecting Competences and Pedagogical Approaches for Sustainable Development in Higher Education: A Literature Review and Framework Proposal. Sustainability 2017, 9, 1889. [CrossRef]

49. Giesenbauer, B.; Müller-Christ, G. University 4.0: Promoting the Transformation of Higher Education Institutions toward Sustainable Development. Sustainability 2020, 12, 3371. [CrossRef]

50. Blanco Portela, N.; Poza Vilches, M.D.; Junyent Pubill, M.; Collazo Expósito, L.; Solís Espallargas, C.; Benayas del Álamo, J.; Gutiérrez Pérez, J. Estrategia de investigación-acción participativa para el desarrollo profesional del profesorado universitario en educación para la sostenibilidad: "Academy sustainability Latinoamérica" (ACSULA). Profr. Rev. Curric. Form. Profr. 2020, 24, 99-123. 